\title{
THE MODEL OF COMMUNITY EMPOWERMENT IN FIRE FOREST DISASTER PREVENTION IN INDONESIA
}

\author{
Husmiati Yusuf ${ }^{1}$, Fahmi Ilman Fahrudin², Adi Fahrudin ${ }^{3}$, Abu Huraerah ${ }^{4}$, \&Wanda Kiyah George \\ Albert $^{5}$ \\ 1 Center for Social Welfare Research and Development, Jakarta, Indonesia \\ 2 Faculty of Science and Technology, University of Muhammadiyah Bandung, Indonesia \\ ${ }^{3}$ Faculty of Social and Political Sciences, University of Muhammadiyah Jakarta, Indonesia \\ 4 Faculty of Social and Political Sciences, University of Pasundan Bandung, Indonesia \\ 5 Faculty of Psychology and Education, Universiti Malaysia Sabah, Malaysia \\ Correspondence authors: fahradi@umj.ac.id
}

\begin{abstract}
This paper will look into the topic of community involvement in forest fire disaster prevention, specifically in Indonesia. To begin, the paper will discuss the problem of forest fires in Indonesia, which occur frequently. The study also addressed issues related to disaster management, such as a lack of competence and knowledge, which resulted in disaster management ineffectiveness. The paper's third portion discusses the government's involvement in catastrophe management. Several initiatives and support have been implemented.
\end{abstract}

Keyword: Forest fire, disaster, prevention, community empowering

\section{Introduction}

Indonesia is the country with the highest risk of natural disaster. Natural disasters, in general, occur when accidents or events occur that are beyond human control; however, natural disasters, particularly the forest and land fire problems in Indonesia, are classified as a combination of natural and man-made disasters (Fahrudin, 2012). Every year, residents of some Sumatra and Kalimantan provinces have been affected by land and forest fires. The cause of the disaster was determined to be smoke, and the government made numerous attempts to extinguish the fire. Nonetheless, the disaster is repeated year after year in this republic. Perhaps the time has come to increase community involvement and preparedness in the prevention of forest and land fires.

Massive forest and land fires, particularly in Riau Province and other parts of Sumatera Island, are an annual occurrence (Tacconi \& Ruchiat, 2006). The scope and significance of forest and land fire not only in Riau Province, but also in other provinces of Kalimantan and Sulawesi (Van Nieuwstadt \& Sheil, 2005). Forest fires disaster in Indonesia is a tragic disaster that occurs every year and is out of control, despite the fact that studies have been conducted to investigate the consequences of forest and land fires. Individuals and communities have suffered greatly as a result 
of the disaster. More than 300,000 people are affected by major health issues such as respiratory illnesses caused by haze and smoke. The pollution level also rises up to five times higher than what the World Health Organization considers hazardous levels (Shavit, Shahrabani, Benzion, \& Rosenboim, 2013). Many public services, including hospitals, schools, and airports, have been closed as a result of these factors.

As a result, risk management has become a critical task. Public authorities are in charge of fire prevention, fire risk information, communication, education, and fire suppression. As a result, risk management has become a critical task. Fire prevention, fire risk information, communication, education, and fire emergency management are all the responsibility of public authorities. Meanwhile, the fire risk in Indonesia is poorly managed. These tasks are actually not only the responsibility of the government, but all people must participate in the fire hazard. It means that fire hazards must be addressed not only from a technical standpoint, but also from an organizational and socio-psychological standpoint (Knox \& Clarke, 2012).

People who may be exposed to forest and land fires must be fully informed about the hazards, preventive measures, and appropriate behaviors during the onset of a fire event, as well as their own responsibilities. Authorities must develop pertinent emergency plans, devise coping strategies, and effectively communicate pertinent information to residents and communities as a whole (Goemans \& Ballamingie, 2013). Such tasks go far beyond the 'traditional' firefighting missions of the past. In fact, a shift in the general orientation of fire risk management appears to be obvious (Martell \& Hillier, 2007). In recent years, the Country Fire Authority of Victoria, for example, has introduced a novel approach to fire safety, the "Community Fireguard" program, which is based on community involvement and aims to increase individual responsibility for fire safety and survival strategies (Paton \& Douglas, 2003). Preparedness for the risk of fires is obviously critical, given that not only property but also human lives are at stake. In Australia, for example, bushfires pose a greater threat than anywhere else in the world (Burrows, 2008)

In Indonesia, planning an orientation program for fire risk management based on community participation and enhancing community empowerment for fire prevention and survival strategy is not a priority. The Indonesian government is unable to resolve many issues that arise in their community (Van Nieuwstadt \& Sheil, 2005). Therefore, Community participation and empowerment, as well as government support, are essential. So far, there is little information available about community-based disaster prevention programs. As a result, the need for communities to be well prepared in areas prone to fire disasters must be met by government organizations that provide rescue services (Ledwith, 2001).

\section{Causes of Land and Forest Fire}

Humans are the primary cause of land and forest fires that occur each year in Sumatra and Kalimantan. The situation is deteriorating as a result of the drought and El Nino phenomenon, which will simplify and expand the deployment of fires and cause smoke. Elements that burn the forest and land do so for financial reasons. The first reason is that this is the least expensive method. According to the BNPB, clearing land by burning requires only 600-800 thousand rupiah per hectare, whereas clearing land without the use of fuel costs $3.5-5$ million rupiah (Toriyama et al., 2014).

The second motive is related to land prices, which have skyrocketed as a result of land being burned. According to the CIFOR study, land prices were eight million rupiah before the fire and eleven million rupiah after the fire. Some parties have benefited from these methods of forest and land fires, as well as the economic benefits that go with them. The parties, according to CIFOR, 
are farmers, land claimants, an intermediary seller of land, and oil investors. Forest and land fires will continue to erupt as the palm oil industry expands. Land and forest fires occur as a result of non-compliance, in addition to the economic motives of the various parties (Crowley, Malik, Amacher, \& Haight, 2009)

To address this issue, the Ministry of Agriculture, Ministry of Forestry, Ministry of Environment, and experts formed a joint audit compliance team. The team aims to get thorough information about the level of compliance of companies and local governments (Tacconi \& Ruchiat, 2006). The team is attempting to ascertain the source of problems and to meet the company's and local government's commitments to prevent forest fires and land degradation. Furthermore, the investigating team's report includes recommendations for fostering and supervising. The findings indicate that there is no evidence of non-compliance on the part of either businesses or local government (Shavit et al., 2013). The Company does not adhere to them because: peat soil exists in the concession area, the company is unable to maintain its concession area in the event of a conflict with the interests of the residents, there was no reporting of companies prior to the fire, and the company lacks the infrastructure and human resources necessary for prevention. While many people are already participating in addressing land and forest fires, there are still certain barriers to community empowerment. For example, fire suppression has not been ideal in all places due to the lack of community groups equipped with the necessary equipment (Knox \& Clarke, 2012; Martell \& Hillier, 2007).

\section{Impact of Land and Forest Fires}

Smoke from forest fires and wildfires has an adverse effect on human health and has a negative economic impact on society. Thousands of individuals suffer as a result of the contaminated air caused by smoke, with many developing upper respiratory tract infections. Additionally, the dense smoke impairs visibility, complicating residents' daily routines, including the flight delays. Economic indicators indicate a loss of approximately 20 trillion rupiah in less than two months. Apart from human health, land and forest fires have a detrimental effect on the ecology, biodiversity, and global warming. CIFOR revealed that forest fires will wreak havoc on the environment and suffocate water sources. Additionally, fires release carbon dioxide into the atmosphere. According to CIFOR data, carbon dioxide is released at a rate of 1.5 to 2 tons per year, accelerating the rate of global warming (Dennis \& Colfer, 2006).

\section{Efforts to Address Land and Forest Fires}

The government has made various efforts to extinguish the fire. The four steps, namely as:

(1) Extinction of the air with artificial rain and water bombing.

(2) Outages on the ground by a joint team military, police and society.

(3) Law enforcement operations by the police and investigators.

(4) Health care and socializing.

In addition to the efforts, they also provide some recommendations:

(1) Improved policies in areas prone to fires.

(2) The evaluation of concessions.

(3) Strengthening the capacity of local government in the resolution of land conflicts between communities and companies.

(4) Providing guidance and supervision.

(5) Empowering communities by the company.

(6) Support and incentives. 
Various efforts made by the government showed encouraging results and can extinguish a fire in the current year. However, the following year returned fire occurs with the same cause, the impact of widening, and a similar effort will be re-done. It's time disaster before the smoke enters a new phase of harm to people, economy and environment (Mendes, 2009).

\section{The Role of Community in Disaster Mitigation}

The land and forest fire calamity has a direct and immediate impact on society. Local governments will be on the scene when a calamity occurs, but once they have dealt with it, they will quickly depart. Thus, individuals who are constantly on-site should be able to prevent land and forest fires in order to avoid a calamity (Dennis \& Colfer, 2006; Van Nieuwstadt \& Sheil, 2005). Community participation in disaster prevention and forest fire prevention might begin at the village level. Certain communities had local ordinances governing land and forest fire protection. Concerns about the impacts of forest fires and land when local restrictions are enforced at the provincial level prompted this hamlet to regulate. The village regulations state plainly and emphatically that any individual who burns unmanaged property and causes adjacent areas to burn will be fined (Hystad \& Keller, 2008). The laws have been established, and individuals have already paid fines totaling more than 20 million rupiah. The local government did not receive a fine under this mechanism, but acted solely as a middleman between the victim and the burner. Certain village regulations teach an important lesson about catastrophe management in terms of land and forest fires. Individuals can band together on their own initiative to punish others who recklessly burn land. Second, the penalty system acts as a deterrent to the burner. Third, while local ordinances are effective, their scope is restricted to village administration and they are impotent to penalize enterprises that burn land. Learning about regulations and enforcement, here are some things that local governments could have done to ensure that the fire did not recur year after year (Motoyoshi, 2006; Sharma, Kanga, Nathawat, Sinha, \& Pandey, 2012)

Community participation should be enhanced, particularly in addressing land and forest fires in the environment through training and the provision of extinguishing facilities and infrastructure such as;

(1) The local government must weave the partnership between the company and the community in order to avoid conflict.

(2) Mechanisms impose fines on enterprises who burn their concession land on a per-hectare basis. This penalty mechanism will be more effective in terms of deterrence and execution speed than criminal or civil attempts.

(3) Conducting research and developing and implementing relevant technology to replace the process of land burning.

(4) If burning remains an option, it must be carefully managed and monitored to ensure that it does not become prevalent.

\section{Community Empowerment in Fire Forest Disaster}

There are a variety of approaches to engage the community in forest fire prevention; one is to establish an integrated program for regions at danger of forest or agricultural fire. Among a variety of methods, including enforcing strict rules in each community area and instituting a system of fines for intentionally set fires, the local community can also utilize the mechanisms of the warning system, which can provide early warning in the event of a fire in an area; then, the team will attempt to extinguish the fire or immediately contact the authorities for assistance. To guarantee that this process is effective, it is vital to conduct periodical assessments to ensure that each 
community adheres to the program's guidelines on an ongoing basis (Harrison, Page, \& Limin, 2009; Mendes, 2009).

Additionally, consultant services and negotiations involving a small number of farmers and ethnic groups can be conducted, as each region has a unique ethnic composition. Negotiations between the government and non-governmental organizations (NGOs) and farmer and ethnic groups are critical to implementing a development plan that empowers farmers' lives (Boehm \& Boehm, 2003). Several of the descriptions and financial projections assist in diversifying economic activities, land clearing techniques that do not require combustion, and agriculture as a viable alternative to small businesses and entrepreneurship that rely solely on agriculture (Branom, 2012). Farmers become less reliant on agriculture as a result of a few alternative small-scale enterprises, hence lowering agricultural fires. All actions are targeted at empowering communities to ensure the security of their livelihoods as farmers while also lowering the risk of forest fires in peat soil used for agricultural reasons. It is unfortunate because continuous combustion contributes to climate change and adversely affects the state of Indonesia, as well as neighboring countries, frequently pressuring Indonesia to take proactive measures to address land and forest fires, which are extremely detrimental to the economies of countries, particularly those in the Asian region (Nasrul, 2013). It is critical to empower individuals to avert fire disasters by refocusing attention on sustainable hazard mitigation rather than response and recovery (Pearce, 2003). It is suggested that integration of disaster management and community planning is important for this transition to occur. Current methods rarely reflect this synthesis, which is one of the reasons that local decisionmaking processes are devoid of danger awareness. If mitigation techniques are to be successfully implemented, public participation at the local decision-making level must be incorporated into the disaster management process. When catastrophe management and community planning are combined, the consequence is long-term hazard mitigation. According to Zhang and Li (2013), China, as a disaster-prone country, has created an advanced community-based disaster management system, and these disasters exhibit a variety of features, a broad distribution, a high frequency, and significant losses.

Concerning community empowerment in fire prevention in Indonesia, we propose that the action plan for fire prevention education be based on the empowering model developed by Dubois and Miley (2011). The social worker's role is critical in this strategy since it helps to build community capacity and understanding regarding fire prevention. The following steps are included in the action plan:

\section{Partner in collaboration}

Both the government and the public suffer when an unjustified regard for government expertise exists. This perspective imbues government with an erroneous sense of omnipotence and entraps clients in a culture of reliance. Thus, empowerment presupposes that clients-partners, in this case the government and the people, take active, collaborative roles.

\section{Partnership Formation}

Not only should a joint effort have been made in the aftermath of a tragedy, but also prior to the occurrence of any crisis. A social worker will teach and inform disaster victims on how to prevent, cope with, and mitigate the risk and impact of fire disasters, in order for them to be prepared, knowledgeable, and vigilant regarding fire hazards. In this regard, social workers' information to 
the community is critical in ensuring that everyone has a sufficient understanding of disaster management.

\section{Community Participation's Characteristics}

The most critical factor in preventing, recovering from, and rehabilitating fire disasters is community participation. A social worker supports community involvement since catastrophe prevention programs will fail if the community is not involved. Community participation is critical for instilling awareness about the hazards associated with fire disasters in the context of fire disaster prevention.

\section{Defining and Explicitly Stated Obstacles}

Additionally, it is necessary to articulate and anticipate the hazards and dangers connected with a disaster. The majority of communities lack the resources and expertise necessary to recognize disaster-related difficulties and dangers. Given this, education regarding fire saster prevention is critical, and the social worker's responsibility is to educate the community about the hazards and risks involved with the catastrophe.

\section{Recognize Your Assets}

A social worker must first identify the community's resources and strengths, which will be employed to aid in catastrophe prevention, recovery, and rehabilitation. This potential can be realized by utilizing it and ensuring that people are self-sufficient. Outside assistance complements the community's assets and potential. Additionally, the social worker must examine the community's strengths, which include integration, cooperation, tolerance, and cross-cultural cooperation. This is an indication of the community's potential and strengths, which are critical for disaster management.

\section{Capacity Assessment of Community Resources: Enhancing Fire Prevention and Preparedness Education}

The social worker must be familiar with and skilled in the area of risk management, as well as give and utilize essential information in an interactive manner; this is a critical procedure. However, public education and public relations are critical components of this. A significant portion of fire education and public relations is aimed at raising public knowledge and securing community participation in order to maintain safe circumstances. Offering landowners an inspection program is a wonderful way to build relationship between firefighters and the community. Public relations officers for the fire department can help improve the agency's image by thoroughly explaining to the public the obligations and duties of fire fighters. Once the public understands the fire department's role in the community, firefighters may focus on their primary mission of preventing fire-related loss of life and property. Fire education has resulted in a significant drop in fire losses and an increase in safety.

\section{Conclusion}

Giving prompt aid is one of the measures that any party has taken when a crisis occurs. This aid is not limited to disaster relief measures such as food and clothing distribution, but also to home reconstruction. This has occurred frequently throughout history, and is referred to be the classic problem-solving strategy. However, in contemporary issue solving, the technique is not intended to weaken the victims and convert them into dependent, helpless, and powerless individuals., The purpose of this article is to offer an action plan for increasing the community's independence, self-help, and empowerment in the prevention of fire disasters. Public authorities 
are responsible for fire prevention, risk assessment, communication, education, and response to fire emergencies. Their research concentrated on the role of community in the continuum of disaster preparedness, response, and recovery, and we examined how community fits into conceptual frameworks for disaster decision-making. These tasks must be approached from not only a technological standpoint, but also from an economic, management, organizational, and socio-psychological one.

\section{References}

[1] Boehm, A., \& Boehm, E. (2003). Community Theatre as a Means of Empowerment in Social Work: A Case Study of Women's Community Theatre. Journal of Social Work, 3(3), 283-300. http://doi.org/10.1177/146801730333002

[2] Branom, C. (2012). Community-Based Participatory Research as a Social Work Research and Intervention Approach. Journal of Community Practice, 20(1994), 260-273. http://doi.org/10.1093/swr/svu013

[3] Burrows, N. D. (2008). Linking fire ecology and fire management in south-west Australian forest landscapes. Forest Ecology and Management, 255(7), 2394-2406. http://doi.org/10.1016/j.foreco.2008.01.009

[4] Crowley, C. S. L., Malik, A. S., Amacher, G. S., \& Haight, R. G. (2009). Adjacency externalities and forest fire prevention. Land Economics, 85(1), 162-185. http://doi.org/10.3368/le.85.1.162

[5] Dennis, R. A., \& Colfer, C. P. (2006). Impacts of land use and fire on the loss and degradation of lowland forest in 1983-2000 in East Kutai District, East Kalimantan, Indonesia. In Singapore Journal of Tropical Geography (Vol. 27, pp. 30-48). http://doi.org/10.1111/j.1467-9493.2006.00238.x

[6] Fahrudin, A. (2012). Psychosocial Reaction and Trauma After a Natural Disaster: The Role of Coping Behavior. Asian Social Work and Policy Review, 6(3), 192-202. http://doi.org/10.1111/j.1753-1411.2012.00070.x

[7] Goemans, M., \& Ballamingie, P. (2013). Forest as hazard, forest as victim: Community perspectives and disaster mitigation in The aftermath of Kelowna's 2003 wildfires. Canadian Geographer. http://doi.org/10.1111/j.1541-0064.2012.00447.x

[8] Harrison, M. E., Page, S. E., \& Limin, S. H. (2009). The global impact of Indonesian forest fires. Biologist, 56(3), 156-163.

[9] Hystad, P. W., \& Keller, P. C. (2008). Towards a destination tourism disaster management framework: Long-term lessons from a forest fire disaster. Tourism Management, 29(1), 151-162. http://doi.org/10.1016/j.tourman.2007.02.017

[10] Knox, K. J. E., \& Clarke, P. J. (2012). Fire severity, feedback effects and resilience to alternative community states in forest assemblages. Forest Ecology and Management, 265, 47-54. http://doi.org/10.1016/j.foreco.2011.10.025

[11] Ledwith, M. (2001). Community work as critical pedagogy : Freire and. Community Development Journal, 36, 171-182.

[12] Martell, D. L., \& Hillier, F. S. (2007). Forest Fire Management. Handbook Of Operations Research In Natural Resources, 99, 489-509. http://doi.org/10.1007/978-0-387-718156_26

[13] Mendes, P. (2009). Teaching community development to social work students: A critical reflection. Community Development Journal, 44(2), 248-262. 
http://doi.org/10.1093/cdj/bsn001

[14] Motoyoshi, T. (2006). Public perception of flood risk and community-based disaster preparedness. A Better Integrated Management of Disaster Risks: Toward Resilient Society to Emerging Disaster Risks in Mega-Cities, 121-134.

[15] Nasrul, B. (2013). Program of Community Empowerment Prevents Forest Fires in Indonesian Peat Land. Procedia Environmental Sciences, 17, 129-134. http://doi.org/10.1016/j.proenv.2013.02.020

[16] Paton, \& Douglas. (2003). Disaster preparedness: a social-cognitive perspective. Disaster Prevention and Management, 12(3), 210-216. http://doi.org/10.1108/09653560310480686

[17] Sharma, L. K., Kanga, S., Nathawat, M. S., Sinha, S., \& Pandey, P. C. (2012). Fuzzy AHP for forest fire risk modeling. Disaster Prevention and Management, 21(2), 160 171. http://doi.org/10.1108/09653561211219964

[18] Shavit, T., Shahrabani, S., Benzion, U., \& Rosenboim, M. (2013). The effect of a forest fire disaster on emotions and perceptions of risk: A field study after the Carmel fire.

Journal of Environmental Psychology, 36, 129-135. http://doi.org/10.1016/j.jenvp.2013.07.018

[19] Tacconi, L., \& Ruchiat, Y. (2006). Livelihoods, fire and policy in eastern Indonesia. In Singapore Journal of Tropical Geography (Vol. 27, pp. 67-81). http://doi.org/10.1111/j.1467-9493.2006.00240.x

[20] Toriyama, J., Takahashi, T., Nishimura, S., Sato, T., Monda, Y., Saito, H., ... Kiyono, Y. (2014). Estimation of fuel mass and its loss during a forest fire in peat swamp forests of Central Kalimantan, Indonesia. Forest Ecology and Management, 314, 1-8. http://doi.org/10.1016/j.foreco.2013.11.034

[21] Van Nieuwstadt, M. G. L., \& Sheil, D. (2005). Drought, fire and tree survival in a Borneo rain forest, East Kalimantan, Indonesia. Journal of Ecology, 93(1), 191-201. http://doi.org/10.1111/j.1365-2745.2005.00954.x

[22] Zhang, X., Yi, L., \& Zhao, D. (2013). Community-based disaster management: A review of progress in China. Natural Hazards, 65(3), 2215-2239. http://doi.org/10.1007/s11069012-0471-3 